\title{
GRAIN EXPORTS OF THE REPUBLIC OF KAZAKHSTAN
}

\section{ҚАЗАҚСТАН РЕСПУБЛИКАСЫНЫН АСТЫҚ ЭКСПОРТЫ}

\section{ЗЕРНОВОЙ ЭКСПОРТ РЕСПУБЛИКИ КАЗАХСТАН}

\author{
A.O. SYZDYKOVA* \\ $P h D$ \\ G. AZRETBERGENOVA \\ C.E.Sc., Associated Professor \\ Khoja Akhmet Yassawi International Kazakh-Turkish University, Turkestan, Kazakhstan \\ ${ }^{*}$ corresponding author e-mail: azizayesevi@gmail.com \\ A.O. СызДЫқОВА* \\ PhD докторы \\ Г.Ж. АЗРЕТБЕРГЕНОВА \\ Э.Ғ.к., доцент \\ Қ.А. Ясауи атындағы Халықаралық қазақ-түрік университеті, Түркістан, Қазақстан \\ *автордың электрондық поштасы: azizayesevi@gmail.com \\ А.О. СЫзДЫқОВА* \\ доктор $P h D$ \\ Г.Ж. АЗРЕТБЕРГЕНОВА \\ к.э.н., доцент \\ Международный казахско-турецкий университет им. Х.А. Ясави, \\ Туркестан, Казахстан \\ *электронная почта автора: azizayesevi@gmail.com
}

\begin{abstract}
The article analyzes the issues of development of grain market in Kazakhstan. The purpose of the study is to summarize the developments on the competitiveness of economic entities in grain industry, aimed at increasing the sustainability of their functioning in modern conditions of market competition. The authors set the following tasks: to analyze theoretical foundations of the essence and specifics of competitive advantages of grain complex, to identify and systematize the factors affecting its sustainable development, to show the main methods and tools for increasing competitiveness, to assess the current state of development of grain-producing enterprises in the republic. On the basis of the conducted studies, a comprehensive methodology for determining the profitability of grain economic structures was proposed, which consists in analyzing the indicators of their production and technological, organizational and managerial, financial and economic potential by creating effective relationships with suppliers, competitors, contact audience, organizing coordinating relations, marketing activities, allowing to identify promising directions for increasing the competitiveness of grain production in the Republic of Kazakhstan. The implementation of the formulated proposals will strengthen the position of Kazakhstani agricultural producers, will contribute to increasing the volume of high quality products, which will allow the republic to win the competition on the world grain market.
\end{abstract}

Аңдатпа. Мақалада Қазақстандағы астық нарығын дамыту проблемалары талданады. Зерттеудің мақсаты-қазіргі нарықтық бәсекелестік жағдайында олардың жұмыс істеу тұрақтылығын арттыруға бағытталған астық саласының шаруашылық жүргізуші субъектілерінің бәсекеге қабілеттілігі бойынша әзірлемелерді жалпылау. Авторлар келесі міндеттерді алға қойған: астық кешенінің бәсекелестік артықшылықтарының ерекшелігі мен мәнінің теориялық негіздерін талдау, оның тұрақты дамуына әсер ететін факторларды анықтау және жүйелеу, бәсекеге қабілеттілікті арттырудың негізгі әдістері мен құралдарын көрсету, республиканың астық өндіруші кәсіпорындарының қалыптасқан даму жағдайын бағалау. Жүргізілген зерттеулер негізінде Қазақстан Республикасында дәнді дақылдар өндірісінің бәсекеге қабілеттілігін арттырудың перспективалық бағыттарын анықтауға мүмкіндік беретін жеткізушілермен, бәсекелестермен, байланыс аудиториясымен тиімді қатынастар 
$\bullet \bullet \bullet \bullet \bullet \bullet \bullet \bullet \bullet \bullet \bullet \bullet \bullet \bullet \bullet \bullet \bullet \bullet \bullet \bullet \bullet \bullet \bullet \bullet \bullet \bullet \bullet \bullet \bullet \bullet \bullet \bullet \bullet \bullet$ құру, үйлестіру байланыстарын ұйымдастыру, маркетингтік қызмет арқылы олардың өндірістік-технологиялық, ұйымдастырушылық-басқарушылық, қаржы-экономикалық әлеуетінің көрсеткіштерін талдаудан тұратын астық шаруашылығы құрылымдарының рентабельділігін анықтаудың кешенді әдістемесі ұсынылды. Тұжырымдалған ұсыныстарды іске асыру қазақстандық ауыл шаруашылығы тауарын өндірушілердің позицияларын күшейтеді, жоғары сапалы өнім көлемін өсіруге ықпал ететін болады, бұл республикаға әлемдік астық нарығында бәсекелестік күресте жеңіске жетуге мүмкіндік береді.

Аннотация. В статье анализируются проблемы развития рынка зерна в Казахстане. Цель исследования - В обобщении разработок по конкурентоспособности хозяйствующих субъектов зерновой отрасли, направленной на повышение устойчивости их функциониро-вания в современных условиях рыночной конкуренции. Авторами поставлены следующие задачи: проанализировать теоретические основы сущности и специфики конкурентных преимуществ зернового комплекса, выявить и систематизировать факторы, влияющие на его устойчивое развитие, показать основные методы и инструменты повышения конкурентоспособности, оценить сложившееся состояние развития зернопроизводящих предприятий республики. На основе проведенных исследований предложена комплексная методика определения рентабельности зерновых хозяйствующих структур, заключающаяся в анализе показателей их производственно-технологического, организационно-управленческого, финансово-экономического потенциала посредством создания эффективных отношений с поставщиками, конкурентами, контактной аудиторией, организации координирующих связей, маркетинговой деятельности, позволяющих выявить перспективные направления повышения конкурентоспособности производства зерновых культур в Республике Казахстан. Реализация сформулированных предложений усилит позиции казахстанских сельхозтоваропроизводителей, будет способствовать наращиванию объемов продукции высокого качества, что позволит республике выиграть конкурентную борьбу на мировом зерновом рынке.

Key words: agro-industrial complex, production, wheat, products, market, competitiveness, export potential, foreign trade, exporting countries, marketing activities.

Түйінді сөздер: агроөнеркәсіптік кешен, өндіріс, бидай, өнімдер, нарық, бәсекеге қабілеттілік, экспорттық әлеует, сыртқы сауда, экспорттаушы елдер, маркетингтік қызмет.

Ключевые слова: агропромышленный комплекс, производство, пшеница, продукция, рынок, конкурентоспособность, экспортный потенциал, внешняя торговля, страныэкспортеры, маркетинговая деятельность.

Introduction. Wheat is the most widely produced crop in the world and the essential crop in many countries' food, trade and crop rotation systems. The area under crops and production of wheat, which is the essential plant in human diet, and is growing as population growth. Therefore, wheat is one of the best-selling agricultural products in the world. Wheat products, with annual trade volume of 75-80 bln USD, play an important role in world economy. World wheat trade has improved significantly over the past 15 years. According to the World Trade Center, in 2019 wheat exports to the world amounted to 38.2 bln USD [1].

The key sector of agro-industrial complex of Kazakhstan is agriculture, which accounts for $17.6 \%$ of world exports and $15.3 \%$ of world imports [2]. Wheat and barley are the most widely produced grain products in $\mathrm{Ka}$ zakhstan. In 2019, Kazakhstan produced $11.45 \mathrm{mln}$ tons of wheat. Kazakhstan is the 12th largest wheat producer in the world. Kazakhstan is one of the ten largest exporters of grain and wheat to foreign countries, mainly as flour [3].

At very large volume of trade in the world, in 2019 the volume of wheat exported will be $130 \mathrm{mln}$ tons. $16.7 \%$ of world wheat exports is from Russia and the United States for $16.4 \%$. This amount is growing every year and it remains an important food product for wheatproducing countries and a tool of political pressure. The study of the world's main wheat exporters shows that Russia and the United States are followed by Canada, France, Australia, Argentina, Ukraine, Romania, Germany and Kazakhstan.

Research materials and methods. The methodological basis of the study includes the works of domestic and foreign scientists in the field of agricultural development, as well as documents of legislative and executive bodies. 
Research on current situation of Kazakhstan on the world wheat market, as well as export potential of future wheat production has been conducted.

Based on statistical data, production of the world's wheat exporting countries, opportunities and conditions of wheat production in Kazakhstan were compared.

This study is based on secondary data. In the study the harmonized system of products identification and codes (CN of FEA Code) was used. The number of sections of wheat products in the HS system - 1001. Annual data for 2001-2019 are used in the study. The data on foreign wheat trade are taken from the statistical database of the International Trade Center [see 1].
Although there are many methods of measuring competitiveness, in this study the export market share index and published comparative advantage index as method of calculating competitiveness have been used. In fact, these indices are widely used in empirical research due to simple calculations [4]. Export Market Share Index measures the competitiveness of a particular industry on international market.

Today, Kazakhstan has a significant export potential of wheat production in the world.

Results and their discussion. The share of Kazakhstan in world wheat exports is $2.6 \%$ (table 1).

Table 1 - Wheat exports of major countries in the world (mln USD)

\begin{tabular}{|l|c|c|c|c|c|c|c|}
\hline \multicolumn{1}{|c|}{ Country } & \multicolumn{1}{c|}{2015} & \multicolumn{1}{c|}{2016} & \multicolumn{1}{c|}{2017} & \multicolumn{1}{c|}{2018} & \multicolumn{1}{c|}{2019} & $\%$ & 2020 June \\
\hline World & 38714,0 & 36477,2 & 38993.1 & 41201,2 & 38268,2 & 100 & $3608,7,7$ \\
\hline Russia & 3893,2 & 4215,8 & 5791.0 & 8432,5 & 6399,3 & 16,7 & 19234,1 \\
\hline USA & 5635,1 & 5382,8 & 6093.4 & 5458,3 & 6265,9 & 16,4 & 3201,6 \\
\hline Canada & 6229,6 & 4504,6 & 5091.9 & 5711,4 & 5385,4 & 14,1 & 3232,9 \\
\hline France & 4278,7 & 3376,9 & 2993.4 & 4124,8 & 4358,9 & 11,4 & 2694,7 \\
\hline Australia & 4403,4 & 3619,3 & 4674.1 & 3082,0 & 2514,4 & 6,6 & 2163,4 \\
\hline Argentina & 1034,6 & 1867,7 & 2360.1 & 2489,5 & 2450,7 & 6,4 & 1259,2 \\
\hline Ukraine & 2238,2 & 2717,5 & 2759.8 & 3004,4 & 1636,8 & 4,3 & 1227,3 \\
\hline Romania & 769,2 & 1265,1 & 1122.8 & 1233,2 & 1291,7 & 3,4 & 819,4 \\
\hline Germany & 2423,8 & 1934,4 & 1595.5 & 1163,9 & 1254,5 & 3,3 & 645,85 \\
\hline Kazakhstan & 688,7 & 685,1 & 660.8 & 965,4 & 1003,2 & 2,6 & 626,2 \\
\hline Bulgaria & 659,3 & 791,8 & 777.3 & 865,7 & 967,1 & 2.5 & 502,5 \\
\hline Lithuania & 503,4 & 594,7 & 591,6 & 378,4 & 683,5 & 1.8 & 480,5 \\
\hline
\end{tabular}

Table 2 shows export of Kazakhstan to other countries. Kazakhstan exports wheat to the neighboring countries in the south and north, while exports to the west are low.
Today, Uzbekistan, Tajikistan, China, Afghanistan, Azerbaijan and Turkey are the largest exporters of wheat. Kazakhstan will start exporting wheat to Turkmenistan in 2018.

Table 2 - Largest wheat exports of Kazakhstan to other countries (mln USD)

\begin{tabular}{|l|r|r|r|r|r|r|c|}
\hline \multicolumn{1}{|c|}{ Countries } & \multicolumn{1}{c|}{2015} & \multicolumn{1}{c|}{2016} & \multicolumn{1}{c|}{2017} & \multicolumn{1}{c|}{2018} & \multicolumn{1}{c|}{2019} & \multicolumn{1}{c|}{$\%$} & 2020 June \\
\hline World & 688,7 & 685,1 & 660,8 & 965,4 & 1003,2 & 100 & 501,60 \\
\hline Uzbekistan & 206,9 & 201,8 & 198,7 & 285,8 & 372,7 & 37,2 & 186,4 \\
\hline Tajikistan & 184,0 & 165,4 & 166,0 & 159,2 & 197,8 & 19,7 & 99,0 \\
\hline China & 30,2 & 52,4 & 57,5 & 99,0 & 91,4 & 9,1 & 45,8 \\
\hline Afghanistan & 24.8 & 38,4 & 46,4 & 65,7 & 57,0 & 5,7 & 29,2 \\
\hline Turkmenistan & 0,0 & 0,0 & 0,0 & 41,8 & 47,3 & 4,7 & 24,1 \\
\hline Azerbaijan & 19,3 & 9,1 & 13,2 & 51,0 & 45,6 & 4,5 & 21,9 \\
\hline Turkey & 13,0 & 12,6 & 30,8 & 59,6 & 43,6 & 4,3 & 20,8 \\
\hline Russia & 71,8 & 63,2 & 23,8 & 43,2 & 43,3 & 4,3 & 21,6 \\
\hline Italy & 23,5 & 42,4 & 60,0 & 66,8 & 29,9 & 3,0 & 14,3 \\
\hline Kyrgyzstan & 61,3 & 38,6 & 37,9 & 18,1 & 27,7 & 2,8 & 13,6 \\
\hline Georgia & 0,4 & 0,0 & 1,9 & 16,0 & 12,0 & 1,2 & 6,00 \\
\hline Great Britain & 0,0 & 0,9 & 0,0 & 0,0 & 8,6 & 0,9 & 4,5 \\
\hline Tunisia & 0,0 & 1,6 & 4,1 & 6,7 & 5,0 & 0,5 & 2,5 \\
\hline Greece & 0,0 & 0,0 & 0,0 & 3,6 & 3,9 & 0,4 & \\
\hline Sweden & 3,4 & 11,9 & 12,5 & 11,2 & 3,2 & 0,3 & 0,2 \\
\hline
\end{tabular}


Kazakhstan is one of the largest exporters of wheat in the world as well as wheat production volumes. Although Kazakhstan ranks 12th among wheat-producing countries, there are some obstacles in this area.

In Kazakhstan, the yield capacity of winter and spring wheat is $10.1 \mathrm{c} / \mathrm{ha}$. In 2019 , the specified area under crops in general in the country amounted to $221358.0 \mathrm{~km}^{2}$, including the area under wheat $114139.4 \mathrm{~km}^{2}$ [5]. This is $51 \%$ of the total sown area. Although Kazakhstan has fertile soil, there are environmental barriers, such as insufficient water and harsh climate.
There are also structural problems, such as shortage of skilled agricultural workers, dominance of small producers working for their subsistence in key production sectors, weak food supply network and access to foreign markets.

The role of wheat in Kazakhstan's economy and exports is shown in Figure 1. Accordingly, wheat exports in GDP in 2001 amounted to $1.5 \%$, compared to 0,56 in 2007. The high share of wheat exports in GDP in 2001 can be explained by high share of wheat exports in total exports volume. In 2019, the share of Kazakhstan's wheat exports in total exports - $1.5 \%$ (figure 1 ).

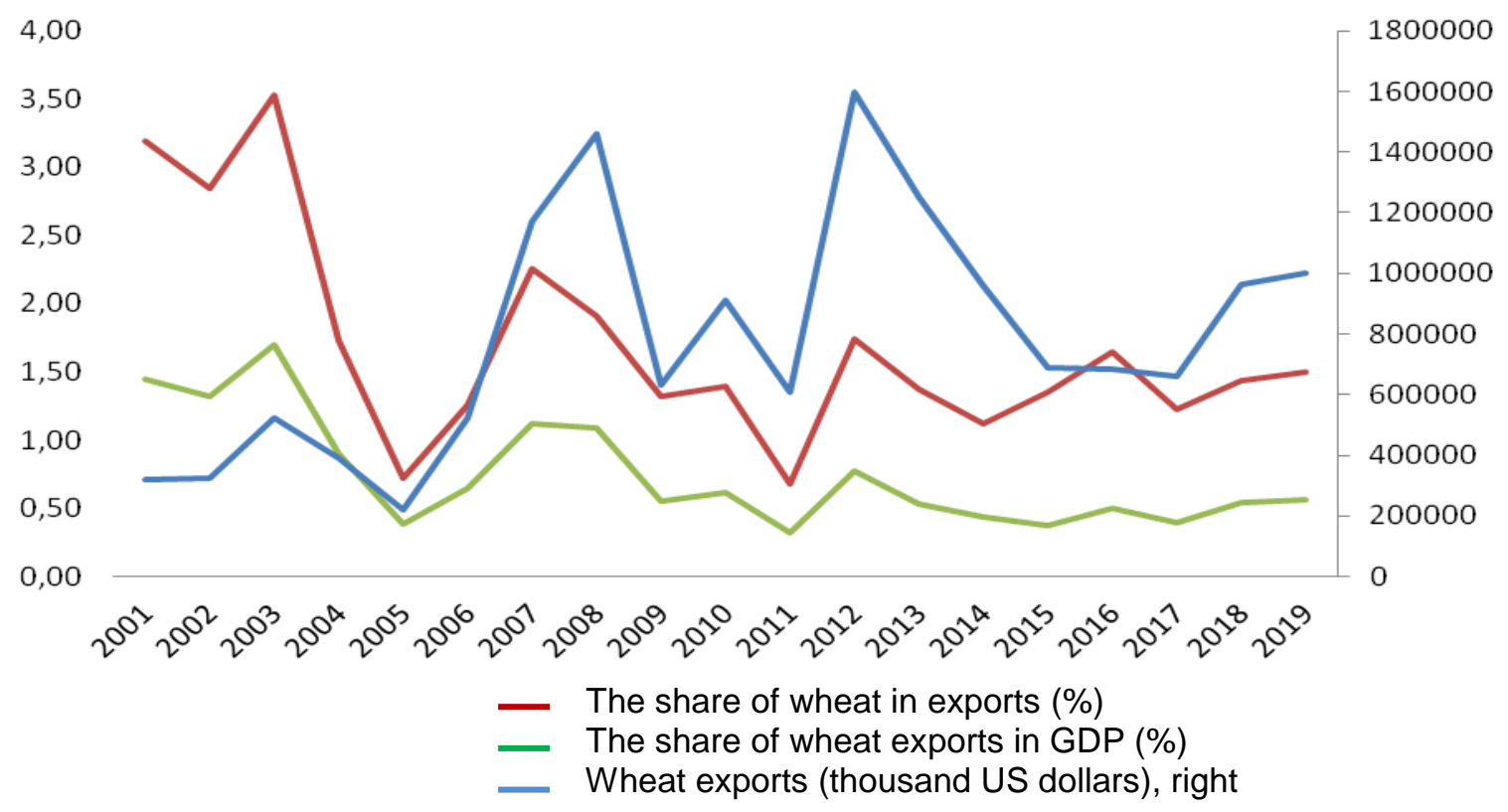

Note: Compiled by the author from Trade Map data (https://www.trademap.org/) and the World Bank data (https://databank.worldbank.org)

Figure 1 - The role of wheat exports in GDP and exports

The index of export market share is the country's percentage ratio to world exports in a particular sector (goods). The index of export market share is formulated as follows [6].

$$
E M S=\left(\frac{x_{i k}}{x_{w k}}\right) \times 100
$$

In Equation $x_{i k}$, ' $\mathrm{i}$ ' represents export of sector ' $k$ ' (product) in the country, ' $k$ ' represents the world export sector (product). The index of export market shares is between 0 and 100. If the country does not export to this sector, the index will be 0 . The fact that the country is the only exporter in this sector leads to the increase of the index to 100 .

The concept of Revealed Comparative Advantage Index (RCA) is based on com- paring the country's indices in the export of particular product with the "world" exports. If the country's productivity is higher than the "world average index", it is concluded that the country has a comparative advantage in this area [7]. In this approach, the commodity structure of foreign trade takes into account the relative costs between countries, as well as non-price factors. The RCA index is used in many studies to identify the strong or weak export sectors of the country [8]. The RCA index is formulated as follows:

$$
R C A_{i j}=\left[\begin{array}{l}
\frac{X_{i j}}{X_{i}} \\
\frac{X_{w j}}{X_{w}}
\end{array}\right]
$$


In Equation 2, RCAij, 'i' represents the comparative advantage index for sector ' $\mathrm{j}$ ' of the country, 'j' sector exports in 'i' country, 'i' country total exports, 'j' sector world total exports, and 'world' total exports. The RCA index has the value between 0 and $\infty$. If the value of the index is immediately higher, then the country has a comparative advantage in this area. In other words, the share of this industry in the country's total exports is higher than its share in world trade. If the value of the index is immediately lower, it indicates that the country does not have a comparative advantage in this area [9].

As mentioned above, the relative advantage depends on whether the value of the index is greater or less than 1. In addition, to show in more detail the strength of the comparative advantage, the Balassa coefficient can be divided into four groups [10]:

- classification: $0<R C A \leq 1$ : no comparative advantage;

- classification: $1<\mathrm{RCA} \leq 2$ : comparative advantage is weak;

- classification: $2<\mathrm{RCA} \leq 4$ : average comparative advantage;

- Classification: 4<RCA: strong comparative advantage.

The increase in the sector's exports does not mean that the country has a comparative advantage in this area. In terms of comparative advantages; It is important that the share of the country's exports in this sector in total exports is higher than the share of exports in this sector in total world exports. In this context, the importance of RCA ratios will be clear in terms of determining the comparative advantages in the exports of countries on the basis of industry and commodity groups.

In terms of competition, the first index used in this study, which examined Kazakhstan's export performance for the period 2001-2019, is the Export Market Share Index (EMS). Figure 2 shows the index of market share of the export markets of two main wheat exporting countries, including Kazakhstan (Russia and the United States). Accordingly, the United States and Russia have the largest share in the world wheat market. In 2019, the value of the Russian EMS index will is 16.72, and the value of the US EMS index - 16.37. The value of the EMS index of Kazakhstan - 2.62. According to these data, the share of Kazakhstan in the world wheat market is very low. During the considered period, the value of the Russian EMS index is constantly growing.

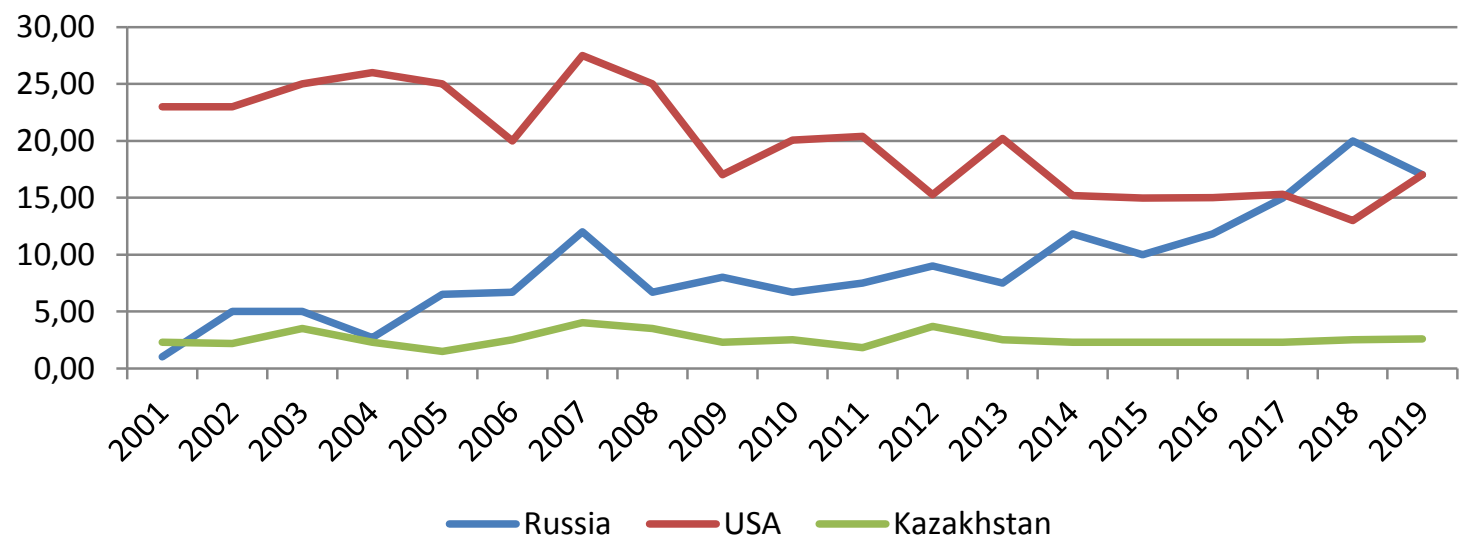

Figure 2 - Export market share in relation to wheat exports index values

The value of the EMS index in Kazakhstan in 2001 was 2.21 , and reached a maximum of 3.84 in 2007. Since 2008, the value of the EMS index has been declining. The most important factor here is the global economic crisis that affected the world in 2008. As a result of the global economic crisis, world trade fell by $12 \%$. The value of the EMS index increased in 2010 and decreased again in 2011. Wheat production was negatively affected by the drought in the country in 2011, which resulted in decline in wheat exports. In 2012, wheat production increased with the improvement of the seasons and, accordingly, exports increased again. As a result, the value of the EMS index reached 3.28 (Figure 2).

At the same time, weak perspectives for the economies of Europe, China and Russia over the past few years has led to reduction of the world wheat prices. This situation has a negative impact on Kazakhstan's export performance. Since 2013, there has been a decline in the EMS index. 
Figure 3 shows the value of the RCA index of the main wheat exporting countries (Kazakhstan and Russia), including Kazakh- stan. As you can see, in 2001 Kazakhstan received the highest value of the $\mathrm{RCA}$ index.

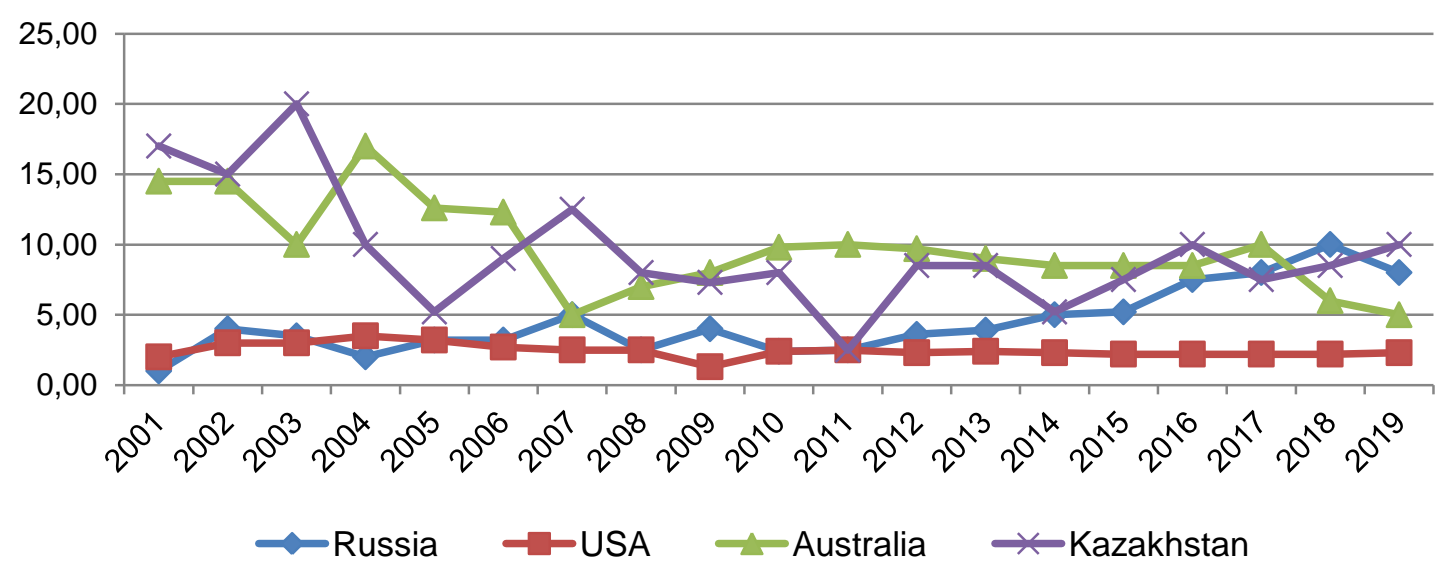

Figure 3 - Comparative advantage for wheat exports index values

By 2019, the highest value of the RCA index belongs to Australia, followed by Kazakhstan, Russia, Canada and the United States. Although the United States has the largest share in the world wheat market, its comparative advantage in the wheat sector is low. However, Canada, Russia and Australia have a comparative advantage in wheat exports. The RCA index of Kazakhstan's wheat exports has been declining in recent years. The RCA index rose from 15.9 in 2001 to 19 in 2003 and declined steadily in the following years. In 2016, the value of the RCA index decreased to 8.14. Today, Kazakhstan's competitiveness in wheat exports is weakening. Increased production costs, growing global competition and stagnation on world markets are putting great pressure on Kazakhstan's competitiveness.

\section{Conclusion.}

1. Kazakhstan is considered to be the "future major player" in the supply of world grain after Russia among the CIS countries. Many experts say that Central Asia, especially Kazakhstan, has the potential to strengthen local, regional and global food security by increasing grain production and exports.

2. Due to the soil and climatic structure, Kazakhstan is a very favorable country for wheat growing. Kazakhstan, with its agroecological potential, meets its needs for wheat, on the other hand, is developing towards becoming a strong participant on the world wheat market.

3. Costs of wheat production in Kazakhstan are relatively low, and transport costs to regional market are low, which gives Kazakhstan an advantage in terms of export costs. However, it is clear that Kazakhstan is not able to fully and effectively assess this potential. After the collapse of the Soviet Union, wheat production and exports declined significantly due to the country's decline and structural problems in agricultural sector. This is due to the fact that Kazakhstan's share in the world wheat market decreased and its competitiveness weakened.

4. Today there are a number of problems associated with wheat production. The most important challenges facing the sector are low efficiency, outdated production technologies, large number of small businesses, and lack of logistics infrastructure. By solving these problems, Kazakhstan's position on the world wheat market will be gradually strengthened. At the same time, in order to increase international competitiveness of Kazakhstan's wheat exports, it is necessary to pay more attention to productivity and quality, and diversification of export market. At the same time, export-oriented governments need to effectively implement incentive policies.

\section{Список литературы}

1 Trade Map// Trade statistics for international business development [Electronic resource].- 2019.- URL: http://www.trademap.org/ (date of access: 28.05.2020).

2 Аймурзина, Б.Т. Қазақстанның аграрлық секторының азық-түлік қауіпсіздігін қамтамасыз етудегі ролі / Б.Т. Аймурзина, М.Ж. Каменова, М. Батай //Проблемы агрорынка.2019.-№2.- Б. 20-26.

3 Нұртазина, Г.С. Қазақстанның агроөнеркәсіптік кешенінің экспорттық әлеуеті/ Г.С. Нұртазина // Проблемы агрорынка.-2019. -№3.- Б. 174-180. 
4 Daulika, P. Analysis on export competitiveness and factors affecting of natural rubber export price in Indonesia/ P.Daulika, Ch.Peng, N.Hanani // Agricultural Socio-Economics Journal.- 2020.-№1.- P. 39-44.

5 Комитет статистики Министерства национальной экономики Республики Казахстан [Электронный ресурc].- 2019.- URL: http:// www.stat.kz. (дата обращения: 28.05.2020).

6 Terin, M. Türkiye kanatlı eti sektörünün uluslararası rekabetçiliğinin seçilmiş ülkelerle karşılaştırılmalı analizi / M. Terin, F. Yavuz //Kahramanmaraş Sütçü İmam Üniversitesi Tarım ve Doğa Dergisi.- 2019.-№22.- P. 189-195.

7 Ivanova, I. On measuring complexity in a post-industrial economy: The ecosystem's approach / I. Ivanova, N. Smorodınskaya, L. Leydesdorff // Quality \& Quantity.- 2020.- №54.P. 197-212.

8 Obadi, S.M. Revealed Comparative Advantage and Competitiveness in the EU-28 and the USA/ S.M. Obadi //Economic Review.2016.-№45.- P. 243-259.

9 Zhaishylyk N., Fang Sun // Kazakhstan's revealed comparative advantages in agricultural exports // Advances in Economics, Business and Management Research (AEBMR): International conference "Transformations and Innovations in ManagementICTIM-17»,2017.-V.37.-P.117-124.

10 Sargsyan A. Export competitiveness: assessment through the Balassa index (the case of Armenia) [Electronic resource].- 2018.- URL: http:// www.preprints.org (date of access: 15.07. 2020).

\section{References}

1 Trade Map// Trade statistics for international business development [Electronic resource].- 2019.- URL: http://www.trademap.org (date of access: 28.05.2020).

2 Aimurzina, B.T. The role of agricultural sector of Kazakhstan in ensuring food security /
B.T. Aimurzina, M.Zh. Kamenova, M. Batay // Problems of Agrimarket.-2019.-№2.- p. 20-26.

3 Nurtazina, G.S. Export potential of Kazakhstan's agro-industrial complex / G.S. Nurtazina // Problems of Agrimarket.- 2019.- №3.P. 174-180.

4 Daulika, P. Analysis on export competitiveness and factors affecting of natural rubber export price in Indonesia / P.Daulika, Ch.Peng, N.Hanan i// Agricultural Socio-Economics Journal.- 2020.- №1.- P. 39-44.

5 Statistics Committee of the Ministry of National Economy of the Republic of Kazakhstan [Electronic resource].- 2019.- URL: http://www. stat.kz. (date of access: 28.05.2020).

6 Terin, M. Türkiyekanatlı etisektörününuluslararası rekabetçiliğininseçilmiş ülkelerlekarşılaştırılmalı analizi / M. Terin, F. Yavuz // Kahramanmaraş Sütçü İmam ÜniversitesiTarımve DoğaDergisi.-2019.-№22.- P. 189-195.

7 Ivanova, I. On measuring complexity in a post-industrial economy: The ecosystem's approach / I. Ivanova, N. Smorodınskaya, L. Leydesdorff // Quality \& Quantity.- 2020.- №54.P.197-212.

8 Obadi, S.M. Revealed Comparative Advantage and Competitiveness in the EU-28 and the USA/ S.M. Obadi//Economic Review.- 2016.№45.- P.243-259.

9 Zhaishylyk N., Fang Sun.// Kazakhstan's revealed comparative advantages in agricultural exports // Advances in Economics, Business and Management Research (AEBMR): International conference «Transformations and Innovations in ManagementICTIM-17»,2017.-V.37.-P.117-124.

10 Sargsyan A. Export competitiveness: assessment through the Balassa index (the case of Armenia) [Electronic resource].- 2018.- URL: http:// www.preprints.org (date of access: 15.07. 2020).

\section{Information about authors:}

Syzdykova Aziza Oralbaikyzy, PhD, Lecturer of Department of Finance and Accounting, Khoja Akhmet Yassawi International Kazakh-Turkish University, 161200, Tauke khan avenue, 29, Turkestan, Kazakhstan, azizayesevi@gmail.com, https://orcid.org/0000-0002-1377-0026

Azretbergenova Gulmira Zharylhasynovna, Candidate of Economic Sciences, Associated Professor, Head of Finance and Accounting Department, Khoja Akhmet Yassawi International Kazakh-Turkish University, 161200, Tauke khan avenue, 29, Turkestan, Kazakhstan, gulaj@mail.ru, https://orcid.org/00000002-9070-7055 